\title{
The impact of the form and frequency of sulphur on pasture yield and composition in South Island high country
}

\author{
M.D. CRAIGHEAD ${ }^{1}$ and A.K. METHERELL ${ }^{2}$ \\ ${ }^{I}$ Nutrient Solutions Ltd, Balcairn, R.D.2, Rangiora \\ ${ }^{2}$ Ravensdown Fertiliser Co-operative Ltd, P.O. Box 1049, Christchurch \\ murray@nutrientsolutions.co.nz
}

\begin{abstract}
Sulphur trials were carried out in the hill and high country of the South Island from 1986/87 to 2000/01. Initial trials showed that sulphur fortified superphosphate fertilisers are more effective products than fine elemental sulphur and sulphur bentonite prills, both in terms of dry matter production and cost effectiveness. This is because Sulphur Super products contain sulphate sulphur and finer elemental sulphur. Sulphur Super Extra (28\% S) was more effective in the short to medium term than Maxi Sulphur Super $(50 \%$ S) largely because it contained more sulphate sulphur. It would be a more preferable option for development, particularly when used at above maintenance rates. It is preferable to apply these products on a biennial rather than a triennial basis to maximise dry matter, maintain better sward composition and to improve the chances of coinciding application with better growth conditions, most notably summer rainfall. Residual elemental sulphur oxidises with time, reducing the dependence on biennial application, although there is still a risk of temporary sulphur deficiency and a delay in response of clover to follow up topdressing if topdressing is left beyond 2 years. Herbage sulphur levels, in conjunction with observation of pasture composition and vigour are useful to indicate when sulphur fertiliser needs to be reapplied.
\end{abstract}

Keywords: sulphate sulphur, elemental sulphur, sulphur bentonite prills, wet mix Sulphur Super, Maxi Sulphur Super, anaerobic nitrogen

\section{Introduction}

South Island dry hill and high country responds well to sulphur fertiliser, due largely to a response in legume growth (Ludecke 1965; McIntosh et al. 1985). Sulphate sulphur $\left(\mathrm{SO}_{4}-\mathrm{S}\right)$ is preferred to elemental sulphur $\left(\mathrm{S}^{0}\right)$ because of its plant availability, but $\mathrm{S}^{0}$ through its subsequent oxidation to $\mathrm{SO}_{4}$-S allows for some residual effect. Elemental sulphur can be added safely to products such as Superphosphate (Super) at up to $30 \% \mathrm{~S}^{0}$ addition (Ministry of Transport 1986). These products are termed dry mix Sulphur Supers and the general assumption is that screened $\mathrm{S}^{0}$ passing a 1 or $2 \mathrm{~mm}$ screen contain particles $<20 \%$ finer than $0.15 \mathrm{~mm}$ and $<35 \%$ finer than $0.25 \mathrm{~mm}$ (A. Duncan pers. comm.). In areas where only sulphur (S) is required, e.g., inland Marlborough this led to investigations into the use of helicopters to apply $\mathrm{S}^{0}$ from a suspended bucket rather than from fixed wing aircraft, the rationale being that the hopper could be jettisoned in the event of a fire. An alternative approach was to look at more concentrated $\mathrm{S}$ products that could be safely applied by fixed wing aircraft and/or mixed with other fertilisers. Two such products were $\mathrm{S}^{0}$ bentonite clay prills (containing $85-90 \% \mathrm{~S}^{0}$ and $10-15 \%$ Na bentonite), and wet mix Sulphur Supers where molten $\mathrm{S}$ is added to Super during manufacture so that fine $\mathrm{S}^{0}$ is incorporated in the granule. These typically contained up to $28-30 \%$ total $\mathrm{S}$. The efficacy of such commercial and experimental products has been previously reported (Craighead et al. 1990; Swanney et al. 1988; Sinclair \& Enright 1983).

During the late 1980s, there were further commercial developments of wet-mix Sulphur Supers with up to $50 \% \mathrm{~S}$ being added. This paper discusses the efficacy of such products and comparisons of other sulphur products in terms of dry matter production, pasture composition and topdressing frequency when applied to extensive hill and high country in the South Island. Data are drawn from several trials to illustrate this.

\section{Materials and Methods}

Data are taken from two sites, one near the Lindis Pass, Otago where a series of experiments were conducted from 1986 to 2001 and a second in the Wairau Valley, Marlborough, 1990-1994.

\section{Sites}

The Lindis Pass site was located at 'Mt. Thomas' on a previously untopdressed high country run-off block, approximately $2 \mathrm{~km}$ south of Lindis Pass, altitude 800 $\mathrm{m}$, rainfall $600-800 \mathrm{~mm}$. The site was on a Meyer soil, a Yellow Grey Earth or Pallic soil (Hewitt 1992), typical of the sunny facing fans, rolling and steepland soils of the South Island high country. The block was primarily used as a summer grazing block. Pasture consisted of low fertility annual grasses, some mouse ear hawkweed (Hieracium pilosella), fescue tussock and some sweet briar. The soil tests for the site were $\mathrm{pH}$ 5.6-5.7, Olsen phosphorus (P) 19-23 mg/ml, MAF quick test (QT) calcium $(\mathrm{Ca})$ 6-7, potassium $(\mathrm{K})$ 7-10, magnesium $(\mathrm{Mg})$ $28-31$ and $\mathrm{SO}_{4}-\mathrm{S} 2-3 \mu \mathrm{g} / \mathrm{g}$. 


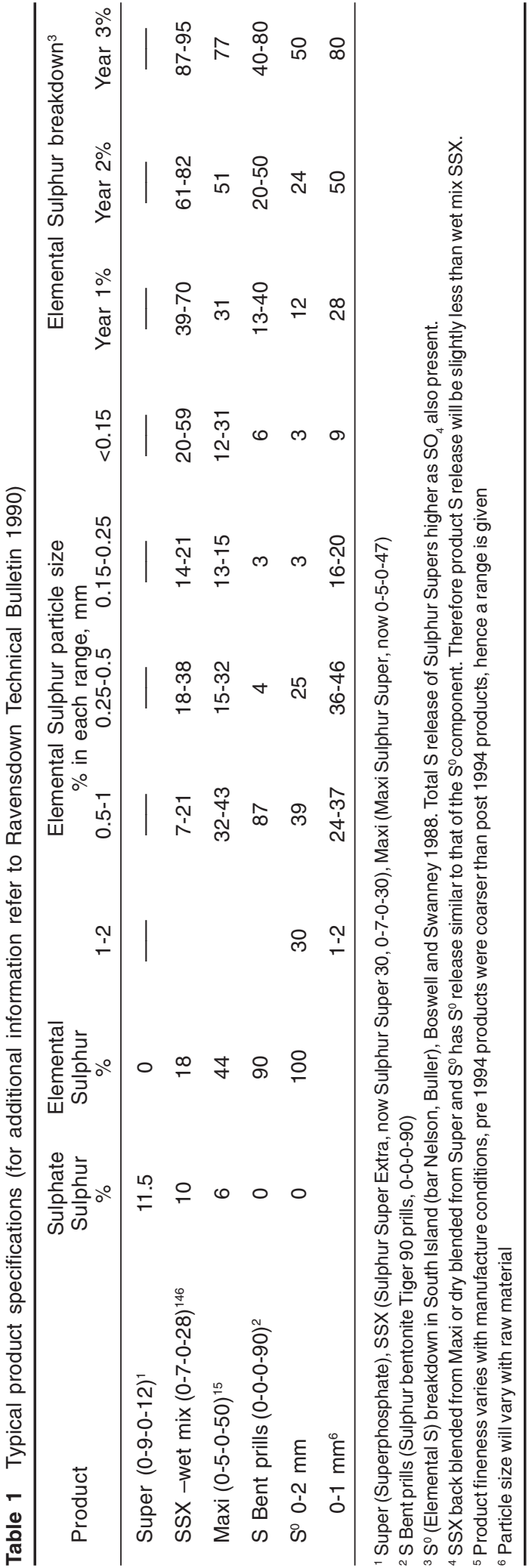

The Wairau site was on a sunny facing Wither hill soil, with a lower $\mathrm{pH}, 5.3$ and Olsen $\mathrm{P}, 8$ but similar $\mathrm{SO}_{4}-\mathrm{S}$ of $2-3 \mu \mathrm{g} / \mathrm{g}$. Other site details are previously described (Craighead 2005).

All trials were mowing trials with some clippings returned to simulate grazing. Plots $\left(16\right.$ or $\left.20 \mathrm{~m}^{2}\right)$ were replicated four times in randomised block designs. Potassium, $15-20 \mathrm{~kg} \mathrm{~K} / \mathrm{ha}$ as potassium chloride was added when required to replace that lost by harvest. Molybdenum ( $65 \mathrm{~g} /$ ha sodium molybdate) was applied at the start of each trial, and $14 \mathrm{~kg} \mathrm{P} / \mathrm{ha}$ triennially as Triple Super to the control plots. Dry matter was harvested three to four times per season, at which time grass, clover and Hieracium cover and, for some trials, soil anaerobic nitrogen $(\mathrm{N})$ measurements (Keeney \& Bremner 1966) were made. Herbage S from paired samples was also measured.

\section{Treatments}

A 6 year trial (L1) compared the efficacy of a range of 'triennial (Craighead et al. 1990)' S treatments including a nil S control, dry mix Sulphur Super Extra (SSX, 0-70-28), Tiger 90 (S-bentonite $90 \% \mathrm{~S}$ ) and $\mathrm{S}^{0}$. A 4 year trial (L2) compared the efficacy of a wet mix SSX with Maxi Sulphur Super (Maxi, 0-5-0-50), Terrasul (Sbentonite $90 \% \mathrm{~S}$ ) and $\mathrm{S}^{0}$ applied biennially. Two further trials compared SSX with Maxi on an annual vs triennial application basis (L3) for 6 years before changing to a biennial vs triennial comparison (L4) for a further 6 years. Product details are given in Table 1.

\section{Results and Discussion}

Dry matter comparisons of various sulphur products Sulphur Super Extra produced significantly more dry matter than screened $\mathrm{S}^{0}$ in all years in both L1 (Fig. 1, $\mathrm{P}<0.05$ ) and L2 (Figure 2, $\mathrm{P}<0.01$ ). These results can best be explained in terms of $\mathrm{S}^{0}$ particle size, as previously established by Ludecke (1965) and McIntosh et al. (1985), and also by the $\mathrm{SO}_{4}-\mathrm{S}$ component in the product (Table 1). Wet mix SSX as used in trial L2 contains the finest $\mathrm{S}^{0}$ which oxidises faster than coarser $\mathrm{S}^{0}$; hence its overall effect is greater. However SSX also contains $\mathrm{SO}_{4}-\mathrm{S}$ which is immediately plant available. The efficacy of $\mathrm{SO}_{4}-\mathrm{S}$ and its better residual effects compared to $\mathrm{S}^{0}$ has been previously established by Ludecke (1965) and the early work of Sinclair and Enright (1983). However the use of sulphate sources such as gypsum, as proposed by these authors, is not cost effective, especially when the phosphate component in Sulphur Supers is also considered. Nor does their work discuss the potential benefit of combining $\mathrm{SO}_{4}-\mathrm{S}$ and $\mathrm{S}^{0}$.

In trial L1 the SSX treatment was a dry blend of Super plus $0-2 \mathrm{~mm} \mathrm{~S}^{0}$ (first application) and 0-1 $\mathrm{mm} \mathrm{S}^{0}$ (second application). This contained sufficient $\mathrm{SO}_{4}-\mathrm{S}$ for 15 
Figure 1 Trial L1, comparison of dry matter production from three sulphur fertilisers applied triennially at $56 \mathrm{~kg}$ S/ha, 1986/87 to 1991/92, Lindis Pass, Otago.

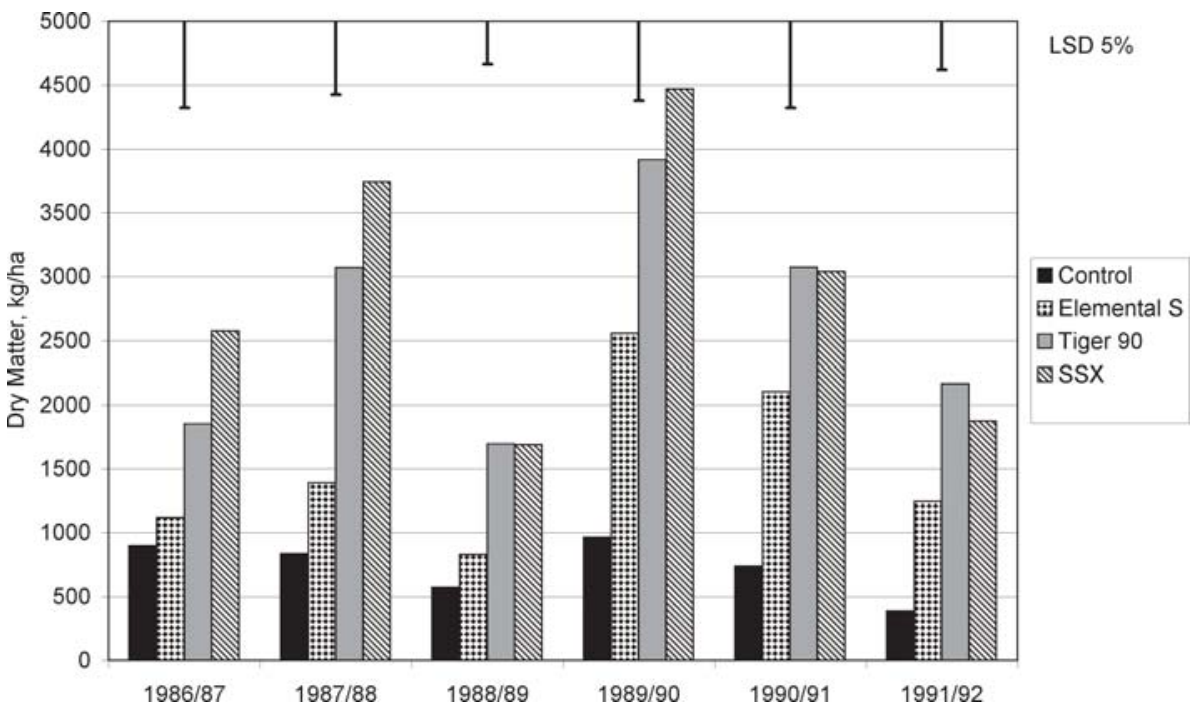

Figure 2 Trial L2, comparison of dry matter production from four sulphur fertilisers applied biennially at $60 \mathrm{~kg}$ S/ha, 1990/91 to 1993/94, Wairau Valley, Marlborough.

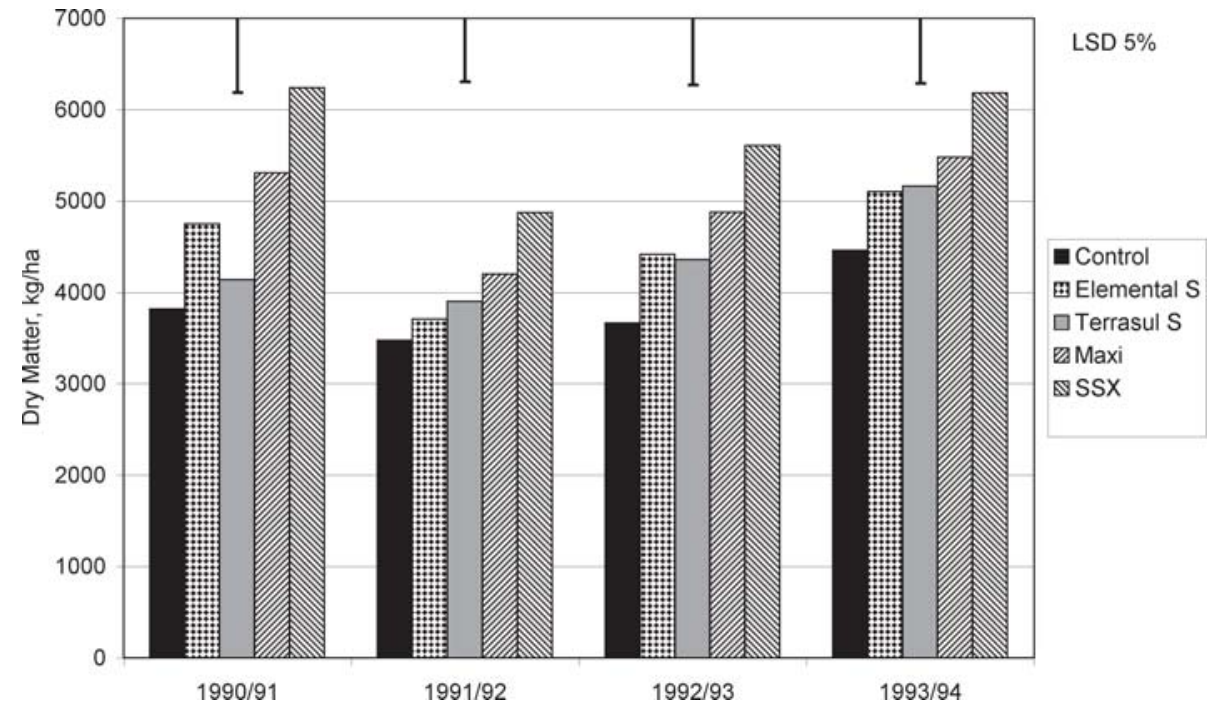

months (Craighead et al. 1990) allowing more time for coarser fractions of $\mathrm{S}^{0}$ to oxidise. After reapplication, particle size was less important as there was still residual $\mathrm{S}^{0}$ oxidising from previous applications, hence differences reduce with time. Elemental S performed well in 1992/ 93, the year after the L1 trial had been completed.

\section{S-bentonite}

Sulphur bentonite products performed variably. Both Sbentonite products contain $\mathrm{S}^{0}$ of an intermediate particle size, but water absorption is first required to expand the clay to disperse the $\mathrm{S}^{0}$ before it can be oxidised to $\mathrm{SO}_{4}$ $\mathrm{S}$. Hence there was a delay in the release of $\mathrm{S}^{0}$. Tiger 90 prills are quite large and performed similarly to SSX from year 3 in trial L1. In contrast, Terrasul bentonite chips which consist of a range of granule sizes performed similarly to $\mathrm{S}^{0}$ over 4 years in trial L2. Previously similar imported and experimental products have performed on par or slightly better than $\mathrm{S}^{0}$ in New Zealand (Swanney et al. 1988, Sinclair \& Enright 1983). In the late 1980s, Ravensdown Fertiliser Co-op Ltd developed a bentonite prill, 'Sulph85' $\left(85 \% \mathrm{~S}^{0}\right)$ with finer overall $\mathrm{S}^{0}$ than 
Figure 3 Trial L3, comparison of dry matter production from annual (19 kg S/ha) vs triennial (57 kg S/ha) application, 1989/90 to 1994/95, Lindis Pass, Otago.

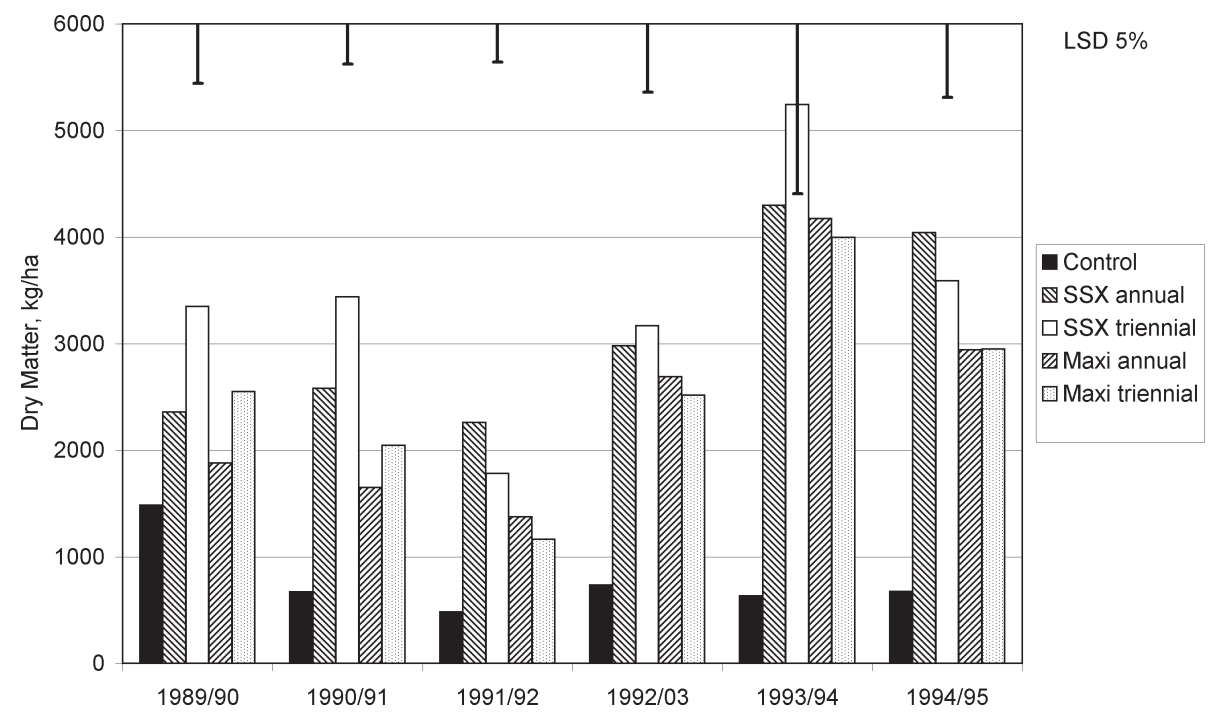

Figure 4 Trial L4, comparison of dry matter production on a biennial (38 kg S/ha) vs triennial $(57 \mathrm{~kg} \mathrm{~S} / \mathrm{ha})$ application, 1995/96 to 2000/01, Lindis Pass, Otago.

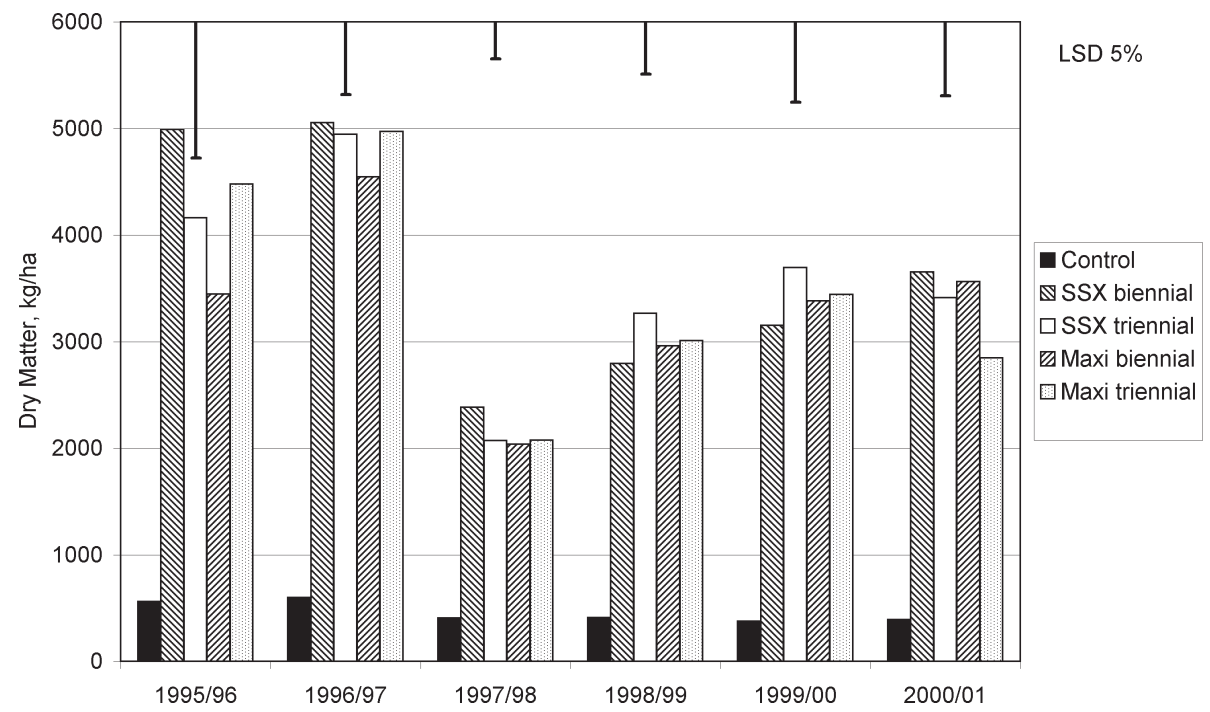

imported products, but it was not commercially viable to manufacture compared to developing more concentrated Sulphur Super products. S-bentonite products would suit maintenance rather than development situations but have not been widely accepted because of their cost.

\section{Maxi Sulphur Super}

Sulphur Super Extra produced significantly $(\mathrm{P}<0.05)$ more dry matter than Maxi in trials L2 and L3 (Figs. 2 \& $3)$, particularly in the year of topdressing. However both are effective $\mathrm{S}$ fertilisers compared to other $\mathrm{S}^{0}$ products.
Sulphur Super Extra performs better partly because of its $\mathrm{S}^{0}$ particle size distribution, and in the short term it's higher $\mathrm{SO}_{4}$-S content (Table 1). It would appear to take 7 years (first year of trial L4, Fig. 4) for the oxidation of residual $\mathrm{S}^{0}$ to contribute equally to growth.

Sulphur Super products can be formulated several ways. Sinclair and Enright (1983) had previously shown that wet mix Sulphur Super was superior to a dry blend of $\mathrm{S}^{0}$ and Super. Although the latter product was the best treatment in L1, on the basis of their work, a wet mix product should have performed better. As the 
Figure 5 Soil anaerobic nitrogen content to $7.5 \mathrm{~cm}$ from both Sulphur Super Extra vs Maxi Sulphur Super trials 1989/90 to 1997/98, Lindis Pass, Otago (6 years of first trial, L3 and first 2 years of second trial, L4).

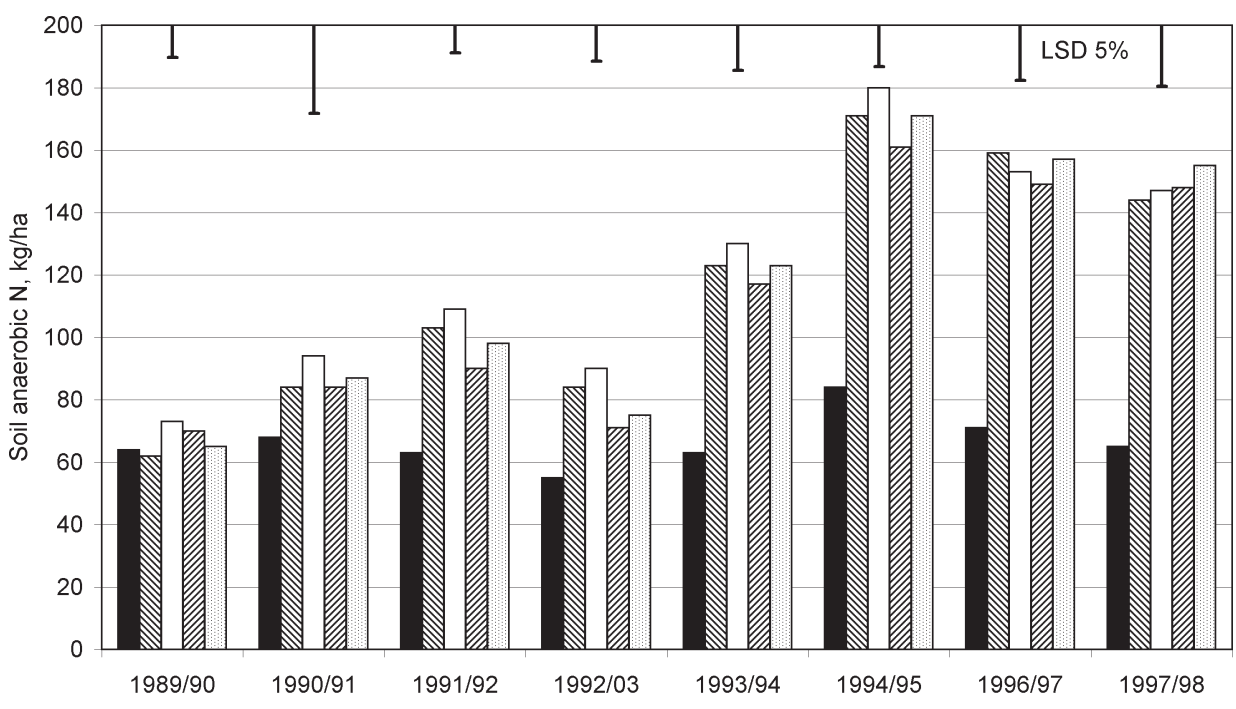

Control $\mathbb{Q} S S X$ annual or biennial $\square$ SSX triennial $\llbracket$ Maxi annual or biennial $\square$ Maxi triennial

Figure 6 Sulphur \% in mixed pasture from both Sulphur Super Extra vs Maxi Sulphur Super trials 1989/90 to 2000/01, Lindis Pass, Otago (each value is the mean of two results)

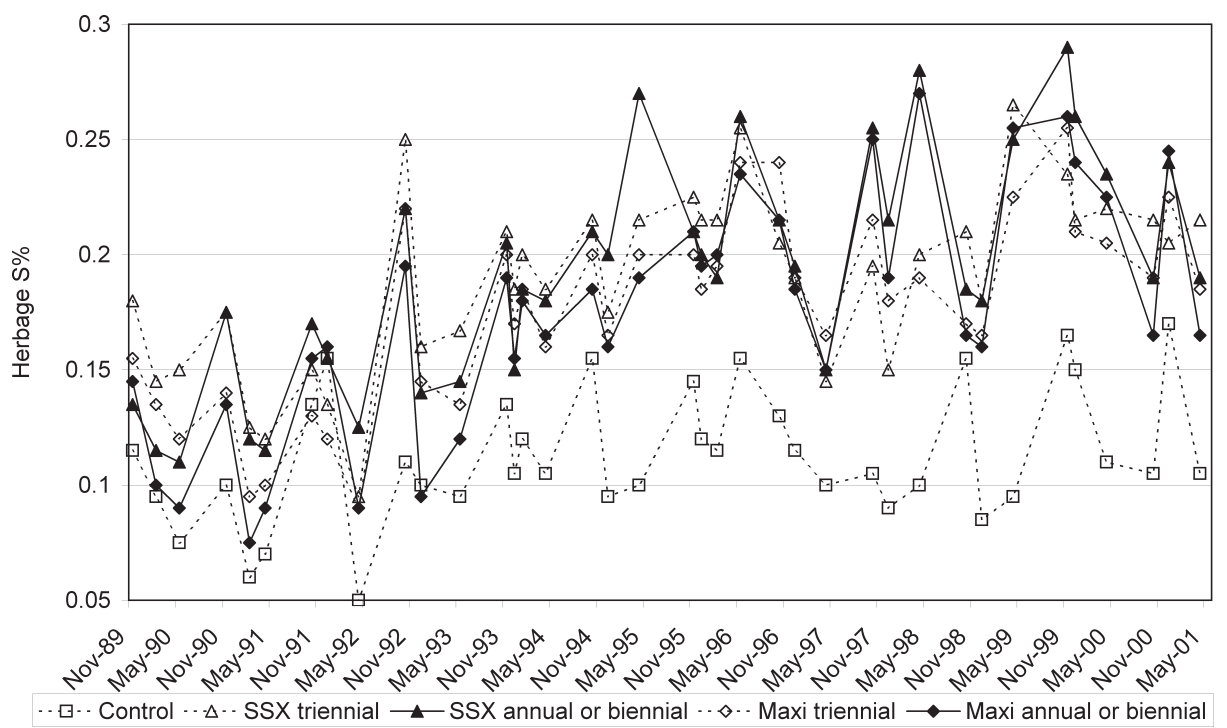

concentration of $\mathrm{S}^{0}$ added to Super during the manufacture of wet mix Sulphur Supers is increased then the particle size of $\mathrm{S}^{0}$ also increases (FLRC Massey University reports to Ravensdown Fertiliser Co-op Ltd). This has agronomic implications to the way less concentrated Sulphur Supers (e.g. Sulphur Super 20) are manufactured. Should they be blended from Maxi and Super or should they be specifically manufactured? A 4 year trial comparing a manufactured SSX of finer particle size to one blended from Maxi and Super, showed no significant difference in dry matter production, hence data are not presented. As both products contained similar amounts of $\mathrm{SO}_{4}$-S this negated any small differences in $\mathrm{S}^{0}$ particle size between Maxi and wet mix SSX (Table 1). Since these trials were completed, manufacturing conditions have improved so wet mix Sulphur Supers now contain even finer $\mathrm{S}^{0}$, e.g. as reflected by the upper limits of fine particle size in Table 
1. Perhaps the most important factor to arise from this trial was a significant $(\mathrm{P}<0.01)$ increase in dry matter production $(22 \%)$ in favour of biennial over triennial application of either product. This was most noticeable on re-topdressing in the third year. Hence timing of application is a major consideration when discussing the form of S.

\section{Frequency of application}

In the first 2 years after application (Fig. 3), an initial triennial application of SSX or Maxi produced significantly more dry matter $(\mathrm{P}<0.05)$ than an annual application due to the amount of $\mathrm{S}$ supplied. At these rates, $\mathrm{SSX}$ in particular supplies sufficient $\mathrm{SO}_{4}-\mathrm{S}$ for the first year's growth, which together with oxidation of the finer $\mathrm{S}^{0}$ is sufficient to maintain this advantage over annual applications for a second year. An annual application performed significantly better in year 3 as there was insufficient oxidation of coarser $\mathrm{S}^{0}$ from triennial treatments, although this was not helped by year 3 being very dry. The residual effect of a single large application of Maxi follows a similar pattern to that of SSX although it was not as effective in the second year as a single application of SSX, highlighting the value of $\mathrm{SO}_{4}-\mathrm{S}$. Of concern is the rapid drop in dry matter production in the third year, first shown in Figure 1. This coincides with a rapid drop in legume content, a good indicator in this environment that $\mathrm{S}$ is becoming limiting. Sinclair and Enright (1983) and McIntosh et al. (1985) also noted declines in production in the third year when $50-56 \mathrm{~kg} \mathrm{~S} / \mathrm{ha}$ was applied. The $56 \mathrm{~kg} \mathrm{~S} / \mathrm{ha}$ applied triennially is in accordance with previous recommendations for SSX of 190-200 kg/ha (Ludecke 1965; McIntosh et al. 1985) for legume establishment on Yellow Grey Earth soils.

Re-topdressing triennial treatments increased dry matter production again and re-established the annual vs. triennial trends observed with SSX and its comparisons with Maxi. The magnitude of the response was initially reduced by a second dry season, but dry matter increased in the wetter summers of 1993/94 and 1994/95. In these two seasons there was generally a smaller difference between annual and triennial Maxi treatments, probably indicating the coarser $\mathrm{S}^{0}$ particles were slowly releasing.

The alteration of annual to biennial application from 1995/96 (Trial L4, Fig. 4) shows there is little difference between 2 or 3 year maintenance topdressing frequencies supporting the view that more regular addition of $\mathrm{SO}_{4}-\mathrm{S}$ and fine $\mathrm{S}^{0}$ allows growth to be maintained while residual coarser $\mathrm{S}^{0}$ from previous topdressing slowly oxidises. Annual dry matter production reflects the variation in seasonal rainfall, e.g., 1995/96 and 1996/97 are wetter seasons. Biennial application would be preferred to triennial application as it increases the chances (by 50\%) that topdressing will coincide with better growing conditions.

Although Maxi can be an effective $\mathrm{S}$ fertiliser compared to $\mathrm{SSX}$ in time, on more $\mathrm{P}$ responsive hill soils, e.g., shady Yellow Grey Earths and Yellow Brown Earths (Brown soils), $\mathrm{S}$ products containing more $\mathrm{P}$ relative to $\mathrm{S}$ may be required. Products such as Sulphur Super 20 or 30 (SSX) can supply both maintenance P and S. Despite this, many high country farmers see Maxi as the most cost effective way to grow more dry matter in extensive hill country, even though it may not optimise dry matter production.

It could be argued that it may be preferable to apply low rates of fertiliser annually in these environments. This is not practical due to the additional cost associated with annual aerial topdressing. Very low rates of Sulphur Supers used annually at $7-12.5 \mathrm{~kg} \mathrm{~S} / \mathrm{ha}(25 \mathrm{~kg} / \mathrm{ha} \mathrm{SSX}$ or Maxi), approximately half maintenance for $90 \%$ optimal growth, have been shown to give more production and carrying capacity in the Mackenzie Basin than one application every 4 years supplying the same amount (Scott et al. 2006).

\section{Soil nitrogen status}

Soil $\mathrm{N}$ data are given for trial $\mathrm{L} 3$ and the first 2 years of trial L4 (Fig. 5). From year 3 (1990/91), S treatments significantly raised soil $\mathrm{N}$ status over the control $(\mathrm{P}<0.05)$. Sulphur super extra treatments had significantly higher soil $\mathrm{N}$ levels than Maxi treatments in years 3 and 4, the two driest seasons. Soil N status gradually built up through the first 3 year topdressing phase but then declined in year 4 following a drop in clover content in the third year. Soil N status was higher in the last 3-4 years, a reflection of better summer moisture conditions. Within season soil $\mathrm{N}$ status also followed moisture status, usually levels were highest in early summer, unless spring conditions were cool, and lowest in autumn (data not presented).

\section{Pasture composition and sulphur content}

Control pasture contained negligible clover (clover data not presented) and had very low $\mathrm{S}$ levels throughout the trial, generally ranging between 0.08 and $0.15 \% \mathrm{~S}$ (Fig. 6). Sulphur treatments gradually lifted herbage $S$ levels over the 12 years of trials L3 and L4. In the initial years, herbage $\mathrm{S}$ levels remained low as clover content rapidly increased and $\mathrm{S}$ was diluted through a larger biomass. Clover content rapidly declined in the third year as was also observed in trial L1. It then rapidly increased through the wet summer of 1993/94 before generally settling down as the soil $\mathrm{N}$ status improved and summer conditions were wetter. Triennial application of SSX generally increased clover content more consistently than 
other treatments in the early years and herbage $\mathrm{S}$ content for the 6 years of trial L3. In the second 6 years (trial L4), herbage $S$ levels generally reflected those treatments topdressed most recently and/or at the highest rate. Although herbage S levels fluctuate seasonally, from 1993/94 most $\mathrm{S}$ treatments have maintained herbage $\mathrm{S}$ levels above $0.17 \%$. An optimum herbage level of 0.18 $0.22 \% \mathrm{~S}$ (Nov/Dec) would seem more realistic for hill and high country than the $0.27-0.32 \% \mathrm{~S}$ normally suggested for mixed New Zealand pasture (Cornforth \& Sinclair 1984). Certainly at levels below $0.15 \%$ clover becomes yellow and/or is absent.

Biennial topdressing with products such as SSX containing both $\mathrm{SO}_{4}-\mathrm{S}$ and an adequate range of $\mathrm{S}^{0}$ particle sizes is seen as the best way to reduce fluctuations in herbage $\mathrm{S}$ and clover content while maintaining better dry matter production and soil $\mathrm{N}$ levels. With time, given regular topdressing, the form and perhaps frequency of topdressing is less important.

\section{ACKNOWLEDGEMENTS}

To the Munro family, 'Rostreiver', Otematata for the use of their 'Mt. Thomas' block, Lindis Pass and to Peter and Owen Neal, 'The Brothers', Wairau Valley for the use of their property for field work. To P. Loganathan and staff at the Fertiliser and Lime Research Centre, Massey University for undertaking S particle size analysis and to Andy Howie for field and laboratory work. Over the years many technical staff from Ravensdown Fertiliser Co-operative have assisted with the 'Mt. Thomas' work, in particular Ron Duffy, Steve Clark and the late Bill Burgess. This work was funded by Ravensdown Fertiliser Co-operative Ltd.

\section{REFERENCES}

Boswell, C.C.; Swanney, B. 1988. The effects of particle size, rate and frequency of application of elemental sulphur on the release of sulphate to lucerne in the Upper Waitaki Basin. pp. 159-168. In: Towards the more efficient use of soil and fertiliser sulphur. Eds. White, R.E.; Currie, L.D. Occasional Report No. 2. Fertiliser and Lime Research Centre, Massey University, Palmerston North.

Cornforth, I.S.; Sinclair, A.G. 1984. Fertiliser and lime recommendations for pastures and crops in New
Zealand. Ministry of Agriculture and Fisheries, Wellington. 2nd Edition.

Craighead, M.D. 2005. The effect of two lime sources on short-term changes in soil $\mathrm{pH}$ under Marlborough hill country pasture. Proceedings of the New Zealand Grasslands Association 67: 155-162.

Craighead, M.D.; Burgess, W.B.; Clark, S.A.; Duffy, R.G. 1990. Development of sunny-facing hill country using different forms of sulphur fertiliser. Proceedings of the New Zealand Grasslands Association 52: 203206.

Hewitt, A.E. 1992. New Zealand Soil Classification, DSIR Land Resources Scientific Report No. 19. DSIR Land Resources, Lower Hutt.

Keeney, D.R.; Bremner, J.M. 1966. Comparison and evaluation of laboratory methods of obtaining an index of soil nitrogen availability. Agronomy Journal 58: 498-503.

Ludecke, T.E. 1965. Further aspects of sulphur nutrition of legumes. Proceedings of the New Zealand Grassland Association 27: 129-138.

McIntosh, P.D.; Sinclair, A.G.; Enright, P.D. 1985. Responses of legumes to phosphorus and sulphur fertilisers on 2 toposequences of North Otago soils, New Zealand. New Zealand Journal of Agricultural Research 28: 505-515.

Ministry of Transport 1986. Flammable Materials: Aerial Application. Civil Aviation Information Circular General Series A80 / 86.

Ravensdown Fertiliser Co-op Ltd, 1990. Technical Bulletin, 5/90, 6pp.

Scott, D.; Robertson, J.S.; Hoglund, J.H. 2006. Considerations in low fertiliser rate application in the high country. New Zealand Journal of Agricultural Research 49: 59-65.

Sinclair, A.G.; Enright, D.P. 1983. Effectiveness of elemental sulphur fertilisers. pp. 164-174. In: Sulphur in New Zealand agriculture. Eds. Gregg, P.E.H.; Syers, J.K. Occasional Report No.4. Fertiliser and Lime Research Centre, Massey University, Palmerston North.

Swanney, B.; Boswell, C.C.; Enright, P.D.; Sinclair, A.G. 1988. A comparative field evaluation of some potential sulphur fertiliser materials. New Zealand Journal of Experimental Agriculture 16: 183-192. 